\title{
Designing an Eportfolio Conceptual Framework to Enhance Written Communication Skills among Undergraduate Students
}

\author{
Khalid Saifullah Mazlan ${ }^{1}$, Linda Khoo Mei Sui ${ }^{2} \&$ Zanariah Jano ${ }^{3}$ \\ ${ }^{1}$ Centre for Languages and Human Development, Universiti Teknikal Malaysia Melaka (UTeM), Malaysia \\ Correspondence: Khalid Saifullah Mazlan, Centre for Languages and Human Development, Universiti Teknikal \\ Malaysia Melaka (UTeM), Hang Tuah Jaya, 76100 Durian Tunggal, Melaka, Malaysia. Tel: 60-17-631-0104. \\ E-mail: khalidsaifullahmazlan@gmail.com
}

\author{
Received: January 16, 2015 Accepted: January 28, 2015 Online Published: June 5, 2015 \\ doi:10.5539/ass.v11n17p35 URL: http://dx.doi.org/10.5539/ass.v11n17p35
}

\begin{abstract}
Eportfolio is a powerful tool to develop students' communication as well as critical thinking skills as it allows students to produce their own reflective written products and foster active learning. This study aims to design an innovative teaching approach to improve students' written communication skills in English which is one of the important soft skills for students entering the workforce. Specifically, this study intends to design an eportfolio conceptual framework that can be embedded into an English course. Furthermore, the interactivity mediated by the social networking platform and students' familiarity using this platform can also elevate their motivation to write in English language. This study contributes to the creation of an innovative teaching approach, a student-centered learning approach that utilizes online technology. The new developed eportfolio framework can also be adopted in other English courses for the purpose of improving students' writing skills in English language. Future research should emphasize on the eportfolio model evaluation, integration with soft skills and students' perception of the use of this web-based tool using Technology Acceptance Model (TAM).
\end{abstract}

Keywords: eportfolio, framework, English language, written communication skills

\section{Introduction}

In the era of globalization and advancement of online technology, there is a need to design an innovative teaching and learning approach that allow an active participation from students in the learning process. This need has also been highlighted by the Malaysia Education Blueprint $(2013$ - 2025) which highlights that in the globalized 21st century, innovative teaching approach is crucial for the development of high-quality human capital. The use of creative and innovative applications of Information and Communication Technology (ICT) is seen as a potential tool to help the development of higher-order thinking skills and transform the process of education. Concurrently, an increasing use of a wide variety of ICT by faculty and students to support teaching and learning process gradually causes a migration of student portfolios towards an electronic format which is also known as electronic portfolios or eportfolio (Khoo, 2012).

Until June 2013, it is estimated about 210,263 graduate students failed to get any job in any sector which make a total of $56 \%$ from the total number of 375,401 unemployment in Malaysia (Utusan Malaysia, 2013). As identified by the 2011 Graduate Tracking Study of the Higher Education Ministry, around 40,000 graduates in Malaysia were still unemployed and about 28,000 to 34,000 graduates failed to secure employment from the year 2008 to the year 2010. Besides, the graph of the number of unemployed graduates by highest certificate obtained in Malaysia indicates a small degree of increment as compared with the year 1998 to the year 2010. Even though the overall rate of unemployment in Malaysia decreased throughout the year, the number of unemployed graduates in Malaysia increased (Department of Statistics [DOS], 2011). Indeed, in 2012, tertiary educated or university graduates are the second largest group of unemployed labours (Razak, Yusof, Syazana, Jaafar, \& Talib, 2014). The 2012 statistic showed that 76,200 graduates are still unemployed and the numbers will increase as all new graduates passing out each year are striving for employment (Borneo Post Online, 2012). This is due to reasons such as poor command of the English language, lack of self-confidence and experience, and poor communication skills (Phang, 2006; The Sun Daily, 2006; The Sun Daily, 2014).

Today's workplace shows that technical skills are inadequate to keep individuals employed as the general consensus among employers indicates that the main problem with graduates is the lack of the soft skills needed 
for productive performance (Robles, 2012; Wei, 2011). Therefore, this study intends to design an eportfolio conceptual framework that can be embedded into an English course to improve students' written communication skills, a critical soft skills needed nowadays (Andrews \& Higson, 2008). According to the Recruitment and Employment Commission (REC), almost 50\% from the overall Curricula Vitae (CVs) received by recruitment consultants have spelling or grammar mistakes. Unexpectedly, the number of graduates aged between 21 to 25 who make this mistake are double as compared to those who did not go on to university (The Guardian, 2009). Thus, soft skills such as English language proficiency and communication skills are crucial for graduates' employment ability (Razak et al., 2014; Wei, 2011). Most of fresh graduates and workers have insufficient skills in English language (The Malaysian Insider, 2014; Yasin et al., 2010). National Higher Education Research Institute (IPPTN) finds that graduates are unable to be employed because of their weaknesses in: (a) mastering command of the English language including communication skills (both oral and writing); (b) generating interpersonal relationship; (c) instilling motivation; and (d) overcoming attitude problems such as unable to work as a team, refused to learn, selfish, overly selective in jobs and ask for a high salary (Wei, 2011). Correspondingly, Baharun and Suleiman (2009) find that oral and written communication are ranked first and second, respectively, in respect of employers' perceptions of what makes graduates marketable. Mitchell (2010) also finds that $73 \%$ reported general communication and $57 \%$ stressing written communication skills as extremely important. Another study mentions that hard skills contribute only $15 \%$ to one's success, whereas $85 \%$ of success is due to soft skills (Wats \& Wats, 2008). For that matter, eportfolio is an excellent tool for reflective learning practices that offers a richer, transformative educational experience for the students and promotes a more profound type of learning. It can also be used to evaluate students' work by using a variety of multimedia artifacts such as images, video, audio, documents, journals, presentations, or projects as well as provide a view into the individual's mind and capabilities (Khoo, 2012; O'Keeffe \& Donnelly, 2013).

\section{Literature Review}

\subsection{Soft Skills and Communication}

Soft skills are personal attributes or characteristics that are interpersonal, broadly applicable and complement hard skills. It is less tangible and harder to quantify, thus makes it difficult to observe, acquire and change. In contrast, hard skills are specific, teachable abilities that can be learned and perfected over time, which involve a person's skill set and ability to perform a certain type of task or activity (Bronson, 2007; Parsons, 2014). Soft skills enhances a person's interaction, work efficiency, and career prospect whereby students should develop and obtain from the institution which later benefit their career (Ministry of Higher Education, Malaysia, 2006).

Wei (2011) shows that most employers are looking for graduates with good soft skills and good command of English language especially in private sectors. Sutton (2002) finds that soft skills are very important that they are ranked by employers as number one differentiator for job applicants and highly significant for potential job hires in all types of occupations and industries. Similarly, communication skills are part of the essential elements of generic skills that are important among university students and these skills have been addressed comprehensively at higher education institutions in Malaysia (Iksan et al., 2012; Said, Mahamod, \& Alias, 2013).

A list of soft skills includes more than communication, but proficient communication skills are important as it allows people to excel in their careers and lead a more satisfying life (Cleveland \& Larkins, 2004). Communication skills are the foundation of all generic skills. In fact, one of the main contributions towards unemployment among graduates in Malaysia is the lack of English language proficiency (Astro Awani, 2014; The Malaysian Insider, 2014; Yasin et al., 2010). This is supported by Daud, Abidin, Sapuan and Rajadurai (2011) when they mention that 30,000 Malaysian graduates had only managed to get casual and temporary work that was below their qualifications such as cashiers and restaurant workers because of their limited English proficiency. According to the Association for Academic Language and Learning (AALL, 2010), English language proficiency can be defined as students' ability to make and communicate meaning in English appropriately either in vocal or written context in concern for using the correct grammar and sentence structure while studying and after graduating. A study conducted by Razak et al. (2014) agree that English language proficiency is the most significant factor that influence unemployment among graduates in Malaysia and poor competency in this language hinders generic skills development. Additionally, the National Graduate Employability Blueprint $(2012$ - 2017) shows that the main problems identified by employers in hiring fresh graduates are poor command of the English language with 56\%; poor character, attitude or personality with $37 \%$; demanding of salary/benefits with $33 \%$; irrelevant Degree or job mismatch with $30 \%$; too choosy selecting jobs/company with $28 \%$; and shallow knowledge in the required field with $24 \%$. 
Effective verbal and written communication decrease the chance of misunderstanding, facilitate the process of deciphering messages, and allows for deeper connections with others (Maguire \& Pitceathly, 2002). A white paper commissioned by Microsoft Corporation and released by International Data Corporation (IDC) shown in Figure 1 reports that, among 20 distinct skills bubbling up to the top in millions of high-growth, high-paying job postings, oral and written communication skills are the most required skills across all occupations. The study also provides insight into the skills students need for the top 60 high-growth, high-wage occupations that will account for 11.5 million new hires and 28 percent of job growth by 2020 (Anderson \& Gantz, 2013).

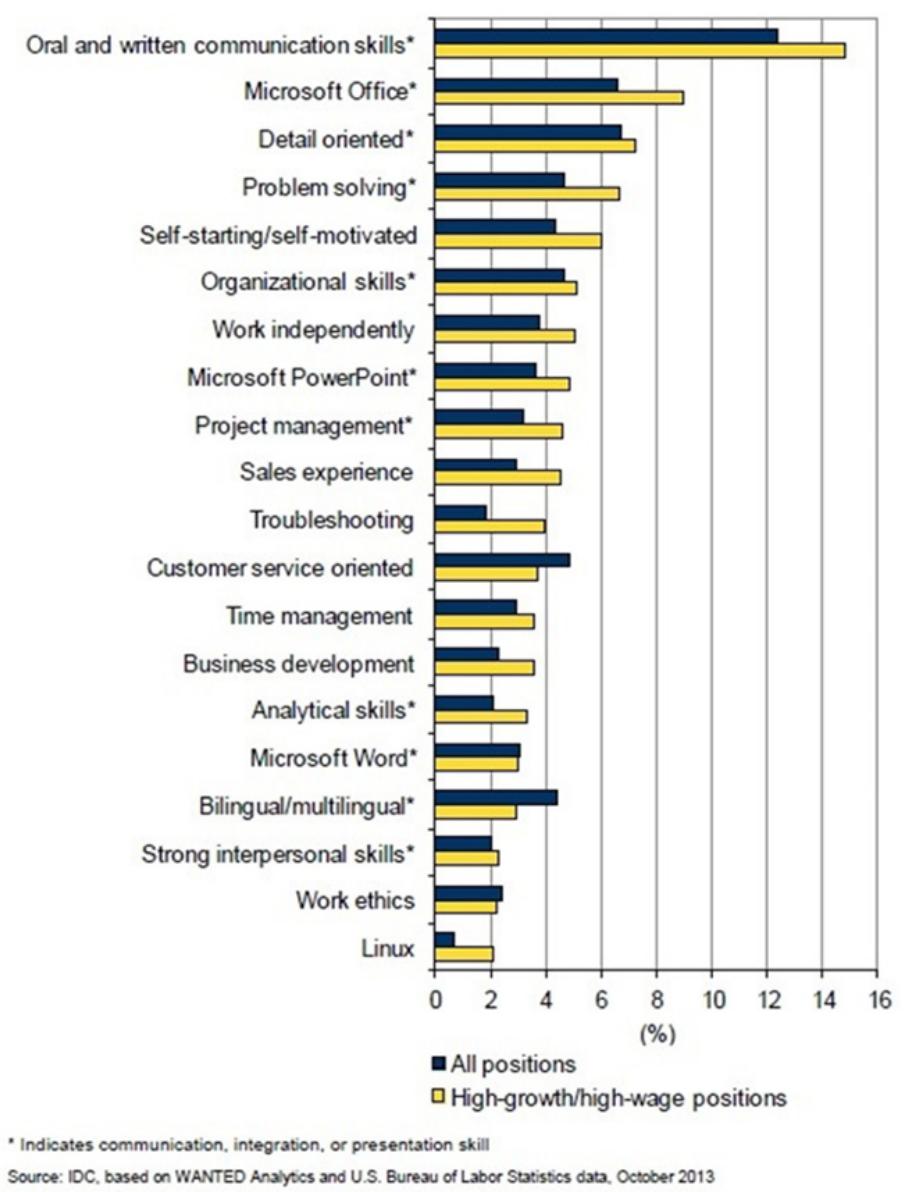

Figure 1. Comparison of the top skills for high-growth/high-wage occupations and all occupations in the United States

Issues regarding undergraduate students lack of soft skills such as communication skills demanded by the job market in Malaysia have been highlighted globally (Shakir, 2009). In fact, during job interviews the prospective employers find that Malaysian graduates lack the communication skills necessary to communicate their knowledge and promote themselves (Nurita, Fatimah, Noor Akmar, \& Hanifah, 2010). As stated by The Engineering School Directory (2010), having an excellent communication skills is one of the top ten qualities of a great engineer where they can write clearly and succinctly, translate complex technical lingo into plain English and also communicate verbally with clients and colleagues. As graduates, they must be able to express their thoughts distinctly and confidently in oral and written forms. Graduates should also be technically savvy and able to give a good presentation with the help of technology (Ministry of Higher Education, 2006).

\subsection{Written Communication Skills}

Written communication is the development and expression of ideas in writing, which involves any type of message that makes use of written words with correct grammar, punctuation, and spelling as its key. It is an important part of communication since employers of graduates often express concern that students graduate with inadequate basic written communication skills as they do not always receive formal teaching in written communication while doing their undergraduate degrees (Griffith University, 2004). Effective written communication should be complete, coherent, concise, clear, concrete, correct, and courteous (Dwyer, 1993, p. 186). Written communication consists of three main elements which are structure (the way the content is laid 
out), style (the way writing is expressed), and content (what the student is writing about) that can be developed through iterative experiences across the curriculum (University of Kent, 2014). Houser (2012) states that written communication involves learning to work with numerous different writing technologies in many genres and styles. It can be defined as the ability to communicate a cohesive and logical message via writing, which employs correct spelling, proper grammar, and proper punctuation when dealing with a range of audiences, in a variety of modes (e.g., persuasion, argument, exposition), as the context requires, using a number of different means (e.g., graphical, statistical, audio-visual and technological). Such writing is acceptable by English standards and typically does not include non-standard or unconventional contractions and abbreviations (Griffith University, 2004; Written Communication, 2012).

\subsection{Eportfolio and Reflection}

Eportfolios are the offspring of printed portfolio. It stores a collection of learners' works (often called 'artifacts') which include products, demonstrations, self-assessments, resources, and accomplishments in digital form rather than physical form that represent an individual, group, or institution (Lorenzo \& Ittelson, 2005). The National Learning Infrastructure Initiative (NLII, 2004) defines an electronic portfolio as "a collection of authentic and diverse evidence, drawn from a larger archive representing what a person or organization has learned over time on which the person or organization has reflected, and designed for presentation to one or more audiences for a particular rhetorical purpose" (p. 22). Eportfolio is the result of the transformation of a previously written portfolio, which is introduced as a means of assessing writing that supported learning through asking students to reflect on and make judgement of their own work (Cambridge, 2010). Unlike portfolio, eportfolio is easier to be used in publishing information and as a learning tool where users can share ideas and information online with other users (Handa, Arame, Goda, Naganuma, \& Gondo, 2011). It is also a useful tool to support integration, synthesis and re-use of formal and informal learning experiences (Tosh et al., 2006).

In addition, electronic systems offer significant advantages in the execution of portfolios including removal of physical size restrictions, variety data inclusion, data storage/backup advantages, increased security, quick logging processes, flexible and can be accessed at anytime and anywhere (Khoo, 2012; Ku \& Chang, 2011; Montgomery \& Wiley, 2008). Reflection and learning are key goals of eportfolio pedagogy (Gallagher \& Poklop, 2014). The learning eportfolio is more student driven in its goals and content with the potential to develop reflective and critical thinking skills, and often consists of students' work from their learning experiences that have been collected, reflected, selected, and presented to show growth and change over time. These works can be stored in a digital archive of learner artifacts that is often called a working portfolio which represents an individual or organization's human capital (Barret \& Wilkerson, 2004).

A process of reflection that goes into composing an eportfolio is central to its impact on learning, does making learner's reflection on artifacts and the story that the eportfolio tells, a critical component (Cambridge, 2010). Moon (as cited in Stefani, Mason, \& Pegler, 2007) defined reflection as "a mental processing form that we use to fulfill a purpose or to achieve some anticipated outcome. It is applied to gain a better understanding of relatively complicated or unstructured ideas and is largely based on the reprocessing of knowledge, understanding and possibly emotions that we already possess". Besides that, reflection is the main component of electronic portfolios that differentiates an eportfolio from a simple repository of artifacts as it assists students to learn from experience and practice, thereby helping them to bridge the theory-practice gap (Gallagher, 2001; Yancey, 2001). It is important because it helps students to manage and understand their learning experienced that includes a jumble of disconnected facts and assignments, as it fits in connecting one topic and discipline to another (Eynon, 2009). Complementary to this, reflective thinking helps in the development of higher order thinking skills among learners by prompting them to (a) relate new knowledge to prior understanding, (b) think in both abstract and conceptual terms, (c) apply specific strategies in novel tasks, and (d) understand their own thinking and learning strategies (Odiba \& Baba, 2013). Reflective learning will be most effective when the contents are personal and 'owned' by the student (McMullan, 2008). Thus, the use of eportfolio in this study supports reflection as it can help students to comprehend their own learning and take charge of their learning process.

Reflective pedagogy transforms eportfolio from a push-button technology into an engaging process of connection, integrating academic learning, life experience, and profound processes of personal growth. Cambridge (2010) asserts that technology can support reflection in three ways: (a) enabling multimedia and hypertextual reflection, (b) scaffolding the learning process, and (c) facilitating interaction with audiences. Eportfolio also provides a place for students to exhibit and reflect on their achievements independently as it is customizable. This enables them to learn, develop, and display their strengths which may help in achieving a greater understanding of their individual growth, career planning, and Curriculum Vitae (CV) building. Reflection on learning has been found to facilitate both lifelong and life-wide learning that enables the learner to 
comment on their collection of evidence (Cambridge, 2008). Apart from that, eportfolio allows students to demonstrate competencies and reflect their learning upon experiences, document academic preparation as well as career readiness, and assists them to map out the future direction (Tosh \& Werdmuller, 2004). Creating an eportfolio enables the enhancement of students learning process by giving them a better understanding of their skills, together with where and how they need to improve to meet academic and career objectives. Students who use eportfolios will also be more responsible for their own learning, understand their strengths and limitations, at the same time learn how to set their goals (Hillyer \& Lye, 1996). The digital artifacts collected by students can also be used to assess learning at the course, programme, department, and institutional level.

\subsection{Eportfolio and Constructivist Learning}

Eportfolio is characterized as a constructive learning tool. In constructivism, learning involves a mental construction where people learn based on their personal interpretation of the world, as people create their own understanding and knowledge of the world through experiencing things and reflecting on those experiences (Duffy \& Cunningham, 1996; Wilson, 1995). In the constructivist learning, learners are not just the passive recipients of information. They become active, reflective, critical, take more responsibility for their own learning, and learn to build knowledge on their own by linking new information to their prior knowledge and determine their own learning outcomes (Batson, 2002). The aim of constructivist learning is to engender independent, self-reliant learners who have the confidence and skill to use a range of strategies to construct their own conceptualizations, knowledge and solutions to problems (Stefani et al., 2007). The concept arose from cognitive and constructivist learning theories (Jonassen, 1991; Von Glasersfeld, 1995) in that students are 'information architects' of their own learning where they construct and provide the evidence demonstrating that learning has taken place with an ongoing assessment, reflection and justification of their knowledge, actions and behaviours. The process assumes that in preparing the eportfolio, learning is enhanced through students' reflection and identification of further learning requirements. In this way, eportfolios promote a learner-centered approach with a focus on reflection and outcomes (Tiwari \& Tang, 2003). In essence, constructivism is concerned with the process of how we construct knowledge, which depends on what learners already know, which in turn depends on the kinds of experiences they have had, how they have managed those experiences into knowledge structures, and their beliefs when interpreting the knowledge (Jonassen, 1995). This learning theory represents philosophical underpinnings that lead to the guidance and development of eportfolio content and design.

\subsection{Frameworks of Eportfolio Process}

There are four common types of conventional portfolio usage in different learning contexts which are assessment, showcase, development, and reflective portfolios (Stefani et al., 2007). Eportfolio can be divided into two major purposes which are (a) promotion of student-centered learning and reflection; and (b) career planning and CV building (Tosh \& Werdmuller, 2004). There is one thing that all eportfolios have in common, the learners must create portfolio elements or artifacts to be presented within the portfolio itself (Cambridge, 2010). In practice, eportfolios can be used in a wide range of learning context and may combine characteristics of the showcase, development and reflective portfolios. Barton and Collins (1993) emphasize, "the first and most significant act of portfolio preparation is the decision of the purposes for the portfolio" (p. 203). Common paradigm in developing portfolio can be either positivist or constructivist as these two paradigms are in conflict with each other (Barret \& Wilkerson, 2004). Barret (2004) also mentions that it is important to differentiate between electronic portfolio (constructivist) and assessment management system (positivist) to avoid confusion in pedagogy. Table 1 shows the differences between these two paradigms as outlined by Leon and Pearl Paulson (1994):

Table 1. A comparison of positivist and constructivist paradigms

\begin{tabular}{ll}
\hline \multicolumn{1}{c}{ Positivist Portfolios } & \multicolumn{1}{c}{ Constructivist Portfolios } \\
\hline $\begin{array}{l}\text { The purpose of the portfolio is to assess learning outcomes } \\
\text { and those outcomes are, generally, defined externally. }\end{array}$ & $\begin{array}{l}\text { The portfolio is a learning environment in which the learner } \\
\text { constructs meaning. It assumes that meaning varies across } \\
\text { individuals, over time, and with purpose. }\end{array}$ \\
$\begin{array}{l}\text { Positivism assumes that meaning is constant across users, } \\
\text { contexts, and purposes. }\end{array}$ & $\begin{array}{l}\text { The portfolio presents process, a record of the processes } \\
\text { associated with learning itself and that a summation of } \\
\text { individual portfolios would be too complex for normative } \\
\text { used to infer what and how much learning has occurred. }\end{array}$ \\
$\begin{array}{ll}\text { The positivist approach puts a premium on the selection of } \\
\text { items that reflect outside standards and interests. }\end{array}$ & $\begin{array}{l}\text { The constructivist approach puts a premium on the selection } \\
\text { of items that reflect learning from the student's perspective. }\end{array}$ \\
\hline
\end{tabular}


In this research study, the eportfolio is developed using Google Blogger (formerly known as Blogspot) and it is fully owned by the students. Blogger is a user-friendly, free blogging platform that requires only a Gmail/Google account to get started, which makes it suitable for novice users. The learning process in developing an eportfolio is being examined by adapting the eportfolio process as 'Plan-Do-Review' cycle by Pallister (2007) with an added elements from Constructivist Paradigm (Barret \& Wilkerson, 2004) and The Learning Landscape Framework (Tosh et al., 2006) as shown in Figure 2. The 'Plan-Do-Review' cycle includes both the approaches of Kolb's Experiential Learning Cycle (Kolb, 1984) and Action Learning (McGill \& Brockbank, 2004) as outlined in Pallister (2007). In Kolb's theory, the impetus for the development of the new concept is provided by new experiences while McGill and Brockbank Action Learning is based on the idea that learning and development should involve real problems, in real life, with real people. These two approaches are based on Constructivist Learning Principles (Jonassen, 1994).

\subsection{1 'Plan-Do-Review’ Cycle (Pallister, 2007)}

Pallister's Plan-Do-Review model supports a social constructivist approach to learning. This cycle involves student-centered learning where the students have to become active, critical and reflective in their learning as well as take responsibility for their learning. It fosters authentic learning when students are placed in the center of the learning process enabling control over their learning. Students are not just the recipient of information, they actively engage in constructing eportfolio, interact with contents and obtain the experience of the learning by planning, selecting, reflecting, and sharing their eportfolio evidence, thereby gain an understanding of the ideas and processes which in turn develops knowledge. Stefani et al. (2007) suggest that the potential for eportfolio to support learning is linked to a student's capability to play an important role in its development.

\subsubsection{Constructivist Paradigm (Barret \& Wilkerson, 2004)}

In the constructivist theory, learner autonomy and initiative are not only accepted, but actively encourage. Likewise, the Constructivist Paradigm emphasis is placed on the student and is focusing on making meaning and assessment as learning through the process of reflecting on students' own learning. Reflective writing not only provide student with valuable feedback from lecturers and peers, but also promoted students' self-awareness of the learning process and required them to assume responsibility for their own learning objectives (Zubizarreta, 2004). Reflection in eportfolios is different from other types of reflection supported by technology because it is a reflection on evidence. As Portland State University has found (as cited in Barrett \& Wilkerson, 2004), hyperlinking in evidence also leads to metacognition which in turn promote deep learning. Evidence in an eportfolio is not just artifacts that a student places in their digital archive, but the artifacts need to be followed by student's rationale, or their argument as to why these artifacts represent their evidence of achieving specific goals, outcomes or standards in order to be considered as evidence of learning. Therefore, having new ways to connect reflective commentary to the features of that evidence could prove powerful (Cambridge, 2010).

More importantly, in 'high stakes' environments, students evidence needs to be validated using a well-developed rubric with distinguishable specific criteria by a trained evaluator such as lecturer and instructor. This can be represented by a simple formula:

$$
\text { Evidence }=\text { Artifacts }+ \text { Reflection }(\text { Rationale })+\text { Validation }(\text { Feedback) }
$$

Students may produce several presentation eportfolios, based on multiple purposes and audiences. Also, this constructivist model supports deep learning by focusing on lifelong, self-directed learning, with an internal locus of control which includes choice of artifacts that results in personalized eportfolio, and focuses on the learner's celebration of uniqueness. In eportfolio, deep learning is supported by facilitating the making of connections between learning experiences that occur in various contexts and environments (Tosh et al., 2006). Barbara Cambridge of the American Association for Higher Education (as cited in Barrett \& Wilkerson, 2004) states that deep learning involves reflection, is developmental, integrative, self-directive and lifelong. Hence, the presentation eportfolios by students may result in a student-centered documentation of deep learning.

\subsubsection{The Learning Landscape (Tosh, Werdmuller, Chen, Light, \& Haywood, 2006)}

This framework gives emphasis on integration and synthesis of learning, regardless of where that learning occurs (e.g., inside or outside the classroom, on campus or off campus, during an undergraduate career or beyond, face to face virtually). The framework allows substitution of emerging technologies as new technologies propose additional ways for reflection and is characterized by three elements:

1) Reflection: The learner maps out their thoughts on a course, a piece of work, or more general experiences.

2) Communication: The learner communicates their reflections to other students, peers, tutors, and lecturers. 
3) Sharing: The learner gives selected other user access to their material (e.g., reflections, artifacts, resources).

The combination of eportfolio and social networks within the learning landscape framework may enhance the prospect for deep learning and provide myriad benefits for the learner as all these tools can facilitate the sharing of reflection; trigger reflective exchange and the creation of audience; and promotes self and peer evaluation. The ability to communicate, collaborate, and share ideas with other learners; pull in information from various research sources; organize and manage own personal learning; form communities of learning or social activity; creates user engagement milieu with peers; and encourage tutor interaction within one or more institution, will eventually foster a level of deeper learning (Klein, 2013).

\section{Methodology}

In designing an eportfolio, the purpose should be clear as it will determine the pedagogies and the process of implementation. Riedinger (2006) asserts that, "the power of eportfolios and reflection can be squandered if their purposes are not clearly defined" (p. 95) as the purpose of the eportfolio will determine the pedagogies and the implementation process. Literature review and qualitative research method have been used to identify suitable pedagogies and framework elements that can be applied in designing an eportfolio framework.

Research on the use of eportfolio for written communication skills enhancement is still infancy. Thus, qualitative research method is the prevalent approach when the theory base is unknown (Creswell, 2003). This view is supported by Morse (1991) when he wrote "characteristics of a qualitative research problem are: (a) the concept is 'immature' due to a conspicuous lack of theory and previous research; (b) a notion that the available theory may be inaccurate, inappropriate, incorrect or biased; (c) a need exists to explore and describe the phenomena and to develop theory; or (d) the nature of the phenomenon may not be suited to quantitative measures" (p. 120).

Qualitative research is a flexible and unobtrusive method that focuses on meaning rather than frequency and quantification. It is characterized by its aims, which relate to understanding behaviours, processes, experiences or perspectives based on the research problem or topic. Meanwhile, content analysis is a research tool used to determine the presence of certain words or concepts within text or sets of texts which allows an analysis of relatively unstructured data in view of the meanings, symbolic qualities, and expressive contents they have. It is done by quantifying and analyzing the presence, meanings, and relationships of such words and concepts, then make inferences about messages within the texts. Texts can be written documents, images, interviews, speech, multimedia, or any communication content (Krippendorff, 2004; Naude, 2008). Qualitative content analysis is a useful alternative when the research involves working with interpretive paradigm to identify important themes or categories within a body of content. This method can also be used to investigate student's reflection about their learning development by analyzing the eportfolio entries to look for patterns before summarization in order to bring meaning to the text (Kabicher, Kriglstein, Figl, \& Motschnig-Pitrik, 2008; Khoo, 2012).

\subsection{Sample and Data Collection}

This research used frameworks, theories and paradigms from previous research studies regarding eportfolio and learning as samples. Data collection from literature review of written text and online documents such as books, journals, articles, and newspaper are being used to gain information and develop a deeper understanding of the eportfolio process, features, elements, implementation and its connection to self-regulated learning.

\subsection{Data Analysis}

Data collected which includes large amounts of textual information is systematically identified based on its properties. As this research emphasizing on constructivist and reflecting learning, data that implemented the constructivist principle will be given priority for analysis. In order to find the important elements, the analyzing process of 'Plan-Do-Review' cycle, Learning Landscape Framework, and Constructivist Paradigm take place by identifying and making comparisons of the processes, features, elements, strengths and weaknesses available in each model. Based on the analysis, a new eportfolio conceptual framework is developed.

\section{Findings}

Based on the literature review, a new conceptual framework of an electronic portfolio process was designed adapting the framework by Pallister (2007) with an added element from Barret and Wilkerson (2004) Constructivist Paradigm and The Learning Landscape by Tosh et al. (2006). The 'Plan-Do-Review' cycle being used as it has been proved to enhance students' graduate attributes based on the previous research conducted by Khoo (2012). In this framework, the cycle begins when students collect artifacts from their learning experiences (specifically in the curriculum of English course) such as cover letter, resume, interview, and meeting outcomes to be put into the eportfolio. They will then select and link those artifacts to a variety of online sources like web pages, articles and YouTube videos to get a clearer picture about the topic. Next, they will review, evaluate, and 
reflect on artifacts by making comparisons between what they have done, reflect upon and what they already know. The students also will evaluate their own learning through reflective commentary and will reflect on their growth and development over time. Those processes will help them to recognize achievement of goals and standards; identifying gaps in development or understanding; and acknowledging skills requiring further work. Also, through the process of reflecting on their own learning, students will select artifacts and written reflections for self-evaluation based on their self-determined purposes. Besides that, students' reflection will be used by the lecturer to gauge their written communication level and understanding of the topic. After the reflection process, students will present and share evidence to their eportfolio followers/subscribers which consist of lecturers and peers from the English course. Students will also share their evidence to social networks such as Facebook, Twitter, and Google+ using hashtags (e.g., \#EPC403letter) provided by the lecturer to encourage broader discussion on the learned topics. The feedback process is formative with the aim of improving student learning, understanding, and quality of the final product. Feedback from the readers (in the form of comments) includes arguments, compliments, corrections, and suggestions on how to correct mistakes, and ways to improve writing skills. The lecturer will teach and guide students on how to give feedback effectively and quality feedback from the students will be awarded with marks. The lecturer will also track and validate students' written communication progress using value rubric provided by the university. Lastly, based on the feedback from lecturer and peers, students will plan and understand what they need to do or produce to rectify the mistakes and overcome their limitations (in the commented topics) before going back into the loop again. Figure 2 illustrates the conceptual framework of the eportfolio:

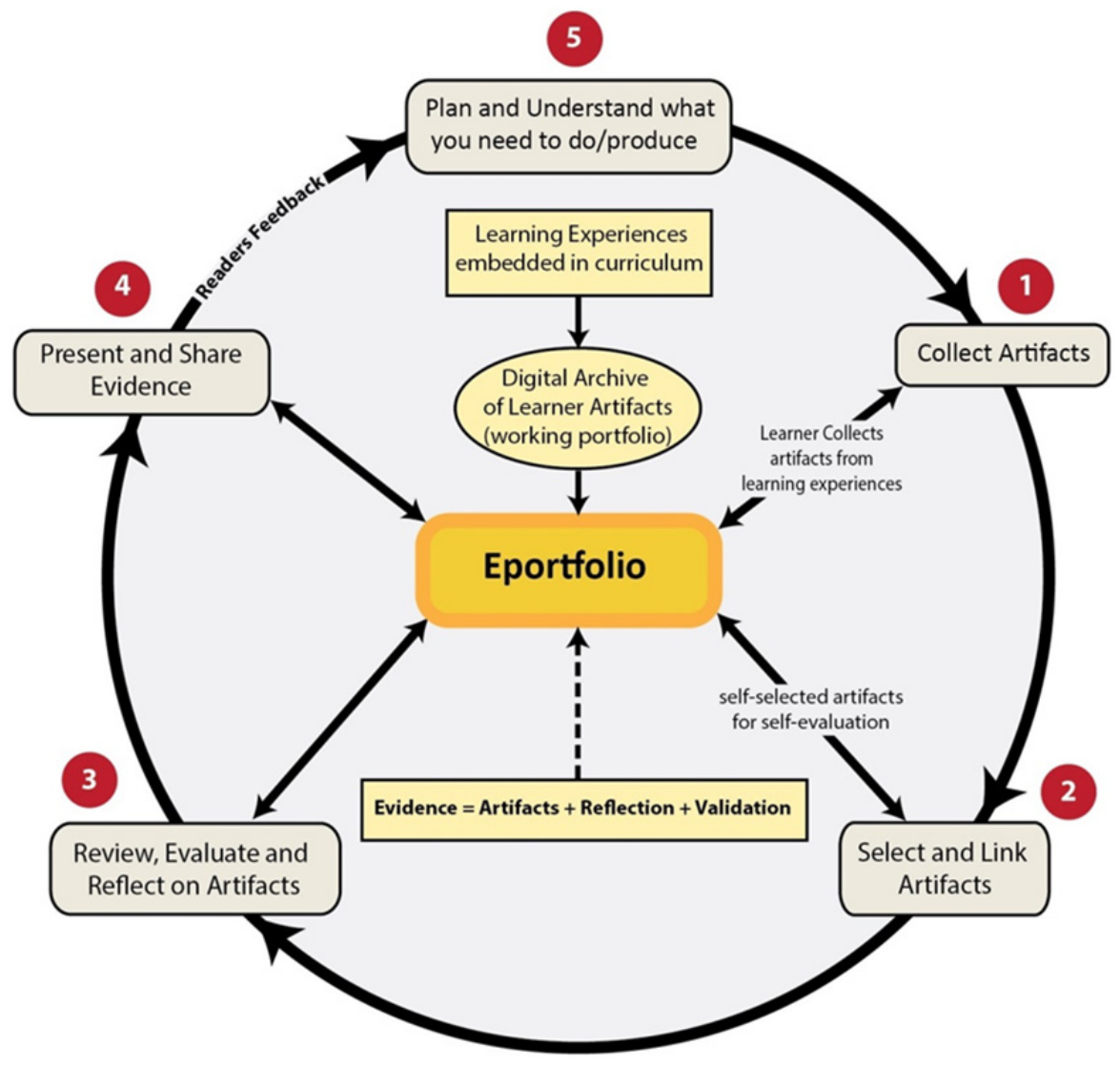

Figure 2. A conceptual framework of eportfolio

\section{Discussion}

This study intends to develop a conceptual framework of the eportfolio process for student self-regulated and reflective learning by using students' voice, with the implementation of the constructivist paradigm to enhance written communication skills among undergraduate students. Blackburn and Hakel (2006) argue that self-regulated learning is a tool which can enhance metacognition, motivation, and task engagement that may 
lead to the improvement of learning and academic performance. Kolb's (1984) Learning Cycle describes the four stages of the learning process as: (a) concrete experience, (b) observation and reflection, (c) formation of abstraction and concepts, and (d) testing in new situations. This cycle involves student-centered learning and the students have to become active. The eportfolio process is ideally suited to support the Kolb's Learning Cycle because it has to do with planning, sharing, doing, reviewing, and reflecting on previous evidence. This is in line with Pintrich's (2004) four stages of self-regulated learning which involves goal setting, monitoring, regulation and reflection.

Learning is achieved through a process that often begins when a learner acts and they are able to see the effect of their action in the situation. Situating student eportfolio within the social context of the web will fosters authentic student voice, enhance peer interactions, expand the boundaries of learning, and facilitates student-centered social content as content associated with social media meshes seamlessly with pedagogical models in empowering student voices (Klein, 2013; Tarantino, McDonough, \& Hua, 2013). In addition, hashtag usage offers an interactive way for course content building besides helping students to track course related content and conversations; identify key topics in a course; and expedites connection and discussion process between them wherever they are (Ivanova, 2013). The use of reflective commentary as written evidence of reflective thinking will also help lecturer to ascertain students' comprehension as well as encourage them to search for answers to their incomprehensibility.

Meanwhile, peer feedback is a critical technique suggested by ample of researchers to improve students' writing because of its social, cognitive, and affective advantages. Through peer feedback, students will have the opportunity to think critically, practice and develop different language skills, acquire greater exposure to ideas, establish a social context for writing, and improve their autonomy (Bijami, Kashef, \& Nejad, 2013). The use of marks in soliciting quality feedback will trigger serious participation and motivate students to put a great deal of effort into the process (Hanrahan \& Isaacs, 2001). Also, active participation from the lecturer and peers is hugely pivotal in boosting student engagement in the learning process (Khoo, 2012; Klein, 2013). Apart from that, learning eportfolio promotes the approach of a constructivist learning theory and the used of constructivist paradigm will help students make meaning of their artifacts through reflection, which is in contrast with the traditional view that learning is all about adding more knowledge. Instead, with eportfolio utilization, learning is based on continuous building and amending of previous structures as new experiences, actions, and knowledge, are assimilated and accommodated to involve a process of individual transformation (Marcoul-Burlinson, 2006).

\section{Conclusion}

In conclusion, eportfolio has the potential as an added tool in learning to enhance written communication skills among students when they engage in the learning process. Besides, choosing a correct eportfolio strategy that matches the framework is important to avoid conflicting paradigms in eportfolio approach. This study suggested strongly that reflective practice is a key to student learning and eportfolios have the capabilities to represent the rich learning journey of students through a showcase of various students' artifacts. The findings of this study may implicate university administrators, faculties, policy makers, and researchers as the newly design conceptual framework can be used in eportfolio development, embedded into the curriculum of the English course, and facilitate students' self-regulated learning that may lead to the promotion of student-centered, active learning experiences. Future research should give emphasize on the eportfolio model evaluation, integration with soft skills, and students' perception of the use of this web-based tool using Technology Acceptance Model (TAM).

\section{Acknowledgment}

The authors would like to thank Universiti Teknikal Malaysia Melaka (UTeM) for its support.

\section{References}

Anderson, C., \& Gantz, J. F. (2013). Skills requirements for tomorrow's best jobs (Helping educators provide students with skills and tools they need) (pp. 4-15). USA. Retrieved from http://news.microsoft.com/ download/presskits/education/docs/idc_101513.pdf

Andrews, J., \& Higson, H. (2008). Graduate employability, "Soft Skills" versus "Hard" business knowledge: A European study. Higher Education in Europe, 33(4), 411-422. http://dx.doi.org/10.1080/037977208025 22627

Association for Academic Language and Learning (AALL). (2010). English language standards for Higher Education. Retrieved from http://www.aall.org.au/sites/default/files/FinalEnglishLanguageStandardsMay 2012.pdf

Astro Awani. (2014, October 11). Malaysian graduates: relevant yet irrelevant? Kuala Lumpur. Retrieved from 
http://english.astroawani.com/news/show/malaysian-graduates-relevant-yet-irrelevant-45433

Baharun, R., \& Suleiman, E. S. (2009). The employers' perception of what makes graduates marketable (pp. 1-17). Academia.edu.

Bijami, M., Kashef, S. H., \& Nejad, M. S. (2013). Peer feedback in learning English writing: Advantages and disadvantages. Journal of Studies in Education, 3(4), 91-97. http://dx.doi.org/10.5296/jse.v3i4.4314

Barrett, H. (2004). Differentiating electronic portfolios and online assessment management systems. Proceedings of the 2004 Annual Conference of the Society for Information Technology in Teacher Education. Retrieved from http://electronicportfolios.org/portfolios/SITE2004paper.pdf

Barrett, H. C., \& Wilkerson, J. (2004). Conflicting paradigms in electronic portfolio approaches. Retrieved from http://electronicportfolios.org/systems/paradigms.html

Barton, J., \& Collins, A. (1993). Portfolios in teacher education. Journal of Teacher Education, 44, $200-211$. http://dx.doi.org/10.1177/002248719304400307

Batson, T. (2002). The electronic portfolio boom: what's it all about?. Campus Technology. Retrieved from http://www.campustechnology.com/articles/39299_1/

Blackburn, J. L., \& Hakel, M. D. (2006). Enhancing self-regulation and goal orientation with eportfolios. In A. Jafari, \& C. Kaufman (Eds.), Handbook of Research on Eportfolios (pp. 83-89). London, UK: IGI Global. http://dx.doi.org/10.4018/978-1-59140-890-1.ch009

Borneo Post Online. (2012, May 14). 76,200 graduates still unemployed - Social activist. Miri. Retrieved from http:/www.theborneopost.com/2012/05/14/76200-graduates-still-unemployed-social-activist/

Bronson, E. (2007). Career and technical education is ideally suited to teaching students the soft skills needed to succeed in the 21 st century workplace. Techniques: Connecting Education \& Careers, 82(7), 30-31.

Cambridge, D. (2008). Audience, integrity, and the living document: Efolio Minnesota and lifelong and life wide learning with eportfolios. Computers \& Education, 51(3), 1227-1246. http://dx.doi.org/10.1016/j.compedu. 2007.11.010

Cambridge, D. (2010). Eportfolios for lifelong learning and assessment (1st ed.). San Francisco, CA: Jossey-Bass.

Cleveland, M. C., \& Larkins, E. R. (2004). Web-based practice and feedback improve tax students' written communication skills. Journal of Accounting Education, 22(3), 211-228. http://dx.doi.org/10.1016/j.jaccedu. 2004.08.001

Creswell, J. W. (2003). Research design: Qualitative, quantitative and mixed methods approaches (2nd ed.). London: Sage Publications.

Daud, S., Abidin, N., Sapuan, N. M., \& Rajadurai, J. (2011). Enhancing university business curriculum using an importance-performance approach: A case study of the business management faculty of a university in Malaysia. International Journal of Educational Management, 25(6), 545-569. http://dx.doi.org/10.1108/ 09513541111159059

Department of Statistics, Malaysia. (2011). Statistics of Graduates in the Labour Force. Malaysia 2011.

Duffy, T. M., \& Cunningham, D. J. (1996). Constructivism: Implications for the design and delivery of instruction. In D. H. Jonassen (Ed.), Handbook of research for educational communications and technology (p. 177). New York: Simon \& Schuster Macmillan.

Dwyer, J. (1993). The Business Communication Handbook (3rd ed.). New York: Prentice Hall.

Eynon, B. (2009). Introduction: Reviewing the literature on reflection and learning. In Transit: The LaGuardia Journal on Teaching and Learning, 4. Retrieved from http://ctl.laguardia.edu/journal/v4/pdf/InTransit Fall09_v4_eynon_intro.pdf

Gallagher, P. (2001). An evaluation of a standards based portfolio. Nurse Education Today, 21(5), 409-416. http://dx.doi.org/10.1054/nedt.2001.0649

Gallagher, C. W., \& Poklop, L. L. (2014). Eportfolios and audience: Teaching a critical twenty-first century skill. International Journal of ePortfolio, 4(1), 7-20. Retrieved from http://www.theijep.com/pdf/IJEP126.pdf

Griffith University. (2004). Written Communication Toolkit. Retrieved from http://www.griffith.edu.au/_data/ assets/pdf_file/0006/162906/written.pdf 
Handa, J., Arame, M., Goda, Y., Naganuma, S., \& Gondo, T. (2011). Using e-portfolios: the impact of online group work. International Journal, 5(1), 75-85.

Hanrahan, S. J., \& Isaacs, G. (2001). Assessing self- and peer-assessment: The students' views. Higher Education Research and Development, 20(1), 53-70. http://dx.doi.org/10.1080/07294360123776

Hillyer, J., \& Lye, T. C. (1996). Portfolios and second graders' self-assessments of their development as writers. Reading Improvement, 33(3), 148-159. Retrieved from http://www.personal.psu.edu/sam7/EDUC586/ Hillyer-LeyArticle.pdf

Houser, L. A. C. (2012). Perceptions of undergraduate students and faculty regarding the impact of electronic communication on the written-communication skills of undergraduate students (Doctoral dissertation, Marywood University, Pennsylvania, United States).

Iksan, Z. H., Zakaria, E., Meerah, T. S. M., Osman, K., Lian, D. K. C., Mahmud, S. N. D., \& Krish, P. (2012). Communication skills among university students. Procedia - Social and Behavioral Sciences, 59, 71-76. http://dx.doi.org/10.1016/j.sbspro.2012.09.247

Ivanova, M. (2013). Understanding microblogging hashtags for learning enhancement. Form@Re - Open Journal Per La Formazione In Rete, 11(74), 17-23. http://dx.doi.org/10.13128/formare-12560

Jonassen, D. H. (1991). Evaluating constructivist learning. Educational Technology, 36(9), 28-33.

Jonassen, D. H. (1994). Thinking technology: Toward a constructivist design model. Educational Technology, 34(4), 34-37. Retrieved from http://search.proquest.com/docview/62815935?accountid=12629

Jonassen, D. H. (1995). Computers as cognitive tools: learning with technology, not from technology. Journal of Computing in Higher Education, 6(2), 40-73. http://dx.doi.org/10.1007/BF02941038

Kabicher, S., Kriglstein, S., Figl, K., \& Motschnig-Pitrik, R (2008). Using eportfolios enhancing for learning through computer-mediated interaction in a course on HCI. http://dx.doi.org/10.1007/978-3-540-89350-9_ 9

Khoo, L. M. S. (2012). Using an eportfolio to enhance graduate attributes among engineering students in Malaysia (Doctoral dissertation, Murdoch University, Perth, Australia). Retrieved from http://researchrepository.murdoch.edu.au/12078/2/02Whole.pdf

Klein, L. F. (2013). The social eportfolio: Integrating social media and models of learning in academic eportfolios. In K. V. Wills, \& R. Rich (Eds.), ePortfolio Performance Support Systems: Constructing, Presenting, and Assessing Portfolios (pp. 57-74). Fort Collins, Colorado: Parlor Press. Retrieved from http://wac.colostate.edu/books/eportfolios/chapter3.pdf

Kolb, D. (1984). Experiential learning: Experience as the source of learning and development. Englewood Cliffs, NJ: Prentice Hall. Retrieved from http://academic.regis.edu/ed205/Kolb.pdf

Krippendorff, K. (2004). Content analysis: An introduction to its methodology (2nd ed.). Thousand Oaks, CA: Sage Publications.

$\mathrm{Ku}, \mathrm{D} . \mathrm{T}$., \& Chang, W. C. (2011). Ufolio: A conceptual design framework for a learning platform and assessment system. Networked Computing and Advanced Information Management (NCM), 2011 7th International Conference, 358-363.

Lorenzo, G., \& Ittleson, J. (2005). An overview of e-portfolios. Educause Learning Initiative Paper 1. Retrieved from http://net.educause.edu/ir/library/pdf/ELI3001.pdf

Maguire, P., \& Pitceathly, C. (2002). Key communication skills and how to acquire them. Bmj, 325(7366), 697-700. http://dx.doi.org/10.1136/bmj.325.7366.697

Marcoul-Burlinson, I. (2006). Eportfolio: constructing learning. In A. Jafari, \& C. Kaufman (Eds.), Handbook of Research on Eportfolios (pp. 168-179). London, UK: IGI Global. http://dx.doi.org/10.4018/978-159140-890-1.ch017

McGill, I., \& Brockbank, A. (2004). The action learning handbook: Powerful techniques for education, professional development and training. Routledge: New York.

McMullan, M. (2008). Using portfolios for clinical practice learning and assessment: The pre-registration nursing student's perspective. Nurse Education Today, 28(7), 873-879. http://dx.doi.org/10.1016/j.nedt. 2007.11.006

Ministry of Higher Education, Malaysia. (2006). Soft skills Development Module for Higher Learning 
Institutions. Kuala Lumpur: Universiti Putra Malaysia Press.

Ministry of Higher Education, Malaysia. (2012). The National Graduate Employability Blueprint 2012 - 2017. Kuala Lumpur: Universiti Putra Malaysia Press.

Ministry of Education Malaysia (MOE). (2013). Malaysia Education Blueprint 2013 - 2025. Kuala Lumpur. Retrieved from http://www.moe.gov.my/userfiles/file/PPP/Preliminary-Blueprint-Eng.pdf

Mitchell, G. W. (2010). Essential soft skills for success in the twenty-first century workforce as perceived by Alabama Business/Marketing Educators (Doctoral dissertation, Auburn University, Alabama, United States). Retrieved from https://etd.auburn.edu/bitstream/handle/10415/1441/Mitchell_Geana_57.pdf

Montgomery, K. K., \& Wiley, D. A. (2008). Building e-portfolios using powerpoint: A guide for educator (2nd ed.). United States: Sage Publication Ltd.

Morse, J. M. (1991). Approaches to qualitative-quantitative methodological triangulation. Nursing Research, 40(2), 120-123. http://dx.doi.org/10.1097/00006199-199103000-00014

National Learning Infrastructure Initiative (EDUCAUSE). (2004). NLII Annual Review: New learning ecosystems (pp. 1-32). Retrieved from https://net.educause.edu/ir/library/pdf/nli0405.pdf

Naude, J. A. (2008). A framework for reporting sustainability performance to major stakeholder groups (Doctoral dissertation, University of South Africa, Pretoria, South Africa). Retrieved from http://uir.unisa.ac.za/bitstream/handle/10500/2597/thesis_naude_a.pdf

Nurita, J., Fatimah, P., Noor Akmar, O., \& Hanifah, M. (2010). Factors influencing internal and external employability of employees. Business and Economics Journal, 2010(BEJ-11), 1-10.

Odiba, I. A., \& Baba, P. A. (2013). Using reflective thinking skills for education quality improvement in Nigeria. Journal of Education and Practice, 4(16), 196-202.

O'Keeffe, M., \& Donnelly, R. (2013). Exploration of eportfolios for adding value and deepening student learning in contemporary higher education. International Journal, 3(1), 1-11.

Pallister, J. (2007). Engaging young learners in the eportfolio process [Video]. Retrieved from http://www.veoh.com/videos/v1257674ChYYanJN

Parsons, T. L. (2014). Definition: Soft skills. Retrieved from http://searchcio.techtarget.com/definition/soft-skills

Paulson, F. L., \& Paulson, P. R. (1994). Assessing portfolios using the constructivist paradigm. (Palatine, Ed.) Annual Meeting of the American Educational Research Association (pp. 1-15). New Orleans, LA: IRI Skylight Training \& Publishing. Retrieved from http://files.eric.ed.gov/fulltext/ED376209.pdf

Phang, S. (2006). Lack of English hinders Malaysian grads. International Herald Tribune. Retrieved from http://www.ytlcommunity.com/commnews/shownews.asp?newsid=26502

Pintrich, P. R. (2004). A conceptual framework for assessing motivation and self-regulated learning in college students. Educational Psychology Review, 16, 385-407. http://dx.doi.org/10.1007/s10648-004-0006-x

Razak, M. I. M., Yusof, A. M., Syazana, W. N., Jaafar, W. E., \& Talib, A. H. (2014). Factors influencing unemployment among graduates in Malaysia-An overview. Journal of Economics and Sustainable Development, 5(11), 168-173.

Riedinger, B. (2006). Mining for meaning: Teaching students how to reflect. In A. Jafari, \& C. Kaufman (Eds.), Handbook of Research on Eportfolios (pp. 90-101). London, UK: IGI Global. http://dx.doi.org/10.4018/978-1-59140-890-1.ch010

Robles, M. M. (2012). Executive perceptions of the Top 10 Soft Skills Needed in Today's Workplace. Business Communication Quarterly, 75(4), 453-465. http://dx.doi.org/10.1177/1080569912460400

Said, N. E. M., Mahamod, Z., \& Alias, A. (2013). Communication and leadership skills: A comparative study of the Malay language specialization trainee teachers in Malaysia. Asian Social Science, 9(16), 1-6. http://dx.doi.org/10.5539/ass.v9n16p142

Shakir, R. (2009). Soft skills at the Malaysian institutes of higher learning. Asia Pacific Education Review, 10(3), 309-315. http://dx.doi.org/10.1007/s12564-009-9038-8

Stefani, L., Mason, R., \& Pegler, C. (2007). The educational potential of e-portfolios. Routledge: London.

Sutton, N. (2002). Why can't we all just get along? Computing Canada, 28(16), 20.

Tarantino, K., McDonough, J., \& Hua, M. (2013). Effects of student engagement with social media on student 
learning: A review of literature. The Journal of Technology in Student Affairs. Retrieved from $\mathrm{http} / /$ studentaffairs.com/ejournal/Summer_2013/EffectsOfStudentEngagementWithSocialMedia.pdf

The Engineering School Directory. "Top 10 Qualities of a Great Engineer". Retrieved from http://www.engineeringschools.com/engineering-top-10.html

The Guardian. (2009, April 21). Spell it out. UK. Retrieved from http://careers.theguardian.com/cv-mistakes

The Malaysian Insider. (2014, June 26). Job seekers with A in SPM English but can't speak a word of it. Petaling Jaya. Retrieved from http://www.themalaysianinsider.com/malaysia/article/job-seekers-with-a-in-spmenglish-but-cant-speak-a-word-of-it

The Sun Daily. (2006, July 4). 70\% of grads from public institutions jobless. Kuala Lumpur. Retrieved from http://www.thesundaily.my/node/173527

The Sun Daily. (2014, March 3). Graduates fail to secure jobs due to poor command of English. Putrajaya. Retrieved from http://www.thesundaily.my/news/973141

Tiwari, A., \& Tang, C. (2003). From process to outcome: the effect of portfolio assessment on student learning. Nurse Education Today 23(4), 269. http://dx.doi.org/10.1016/S0260-6917(03)00012-1

Tosh D., \& Werdmuller, B. (2004). Portfolios and weblogs: one vision for eportfolio development. Retrieved from https://www.academia.edu/3182534/

Tosh, D., Werdmuller, B., Chen, H. L., Light, T. P., \& Haywood, J. (2006). The learning landscape: A conceptual framework for eportfolios. In A. Jafari, \& C. Kaufman (Eds.), Handbook of Research on Eportfolios (pp. 24-32). London, UK: IGI Global. http://dx.doi.org/10.4018/978-1-59140-890-1.ch003

Utusan Malaysia. (2013, November 12). 56 percent of the unemployed are graduates. Retrieved from http://ww1.utusan.com.my/utusan/Parlimen/20131112/pa_02/56-peratus-penganggur-ialah-siswazah

University of Kent. (2014). Communication Skills: Writing. Retrieved from http://www.kent.ac.uk/careers/sk/ written-communication.htm

Von Glasersfeld, E. (1995). A constructivist approach to teaching. In L. Steffe, \& J. Gale (Eds.), Constructivism in Education (pp. 3-16). Lawrence Erlbaum Associates, Inc., New Jersey.

Wats, M., \& Wats, R. K. (2008). Developing soft skills in students. Retrieved from http://108.cgpublisher.com/ proposals/64/index_html

Wei, S. L. (2011). Unemployment among graduates: Study of employers' perception on graduates. Proceeding of the International Conference on Social Science, Economics and Art 2011 (pp. 15-18), Malaysia.

Wilson, B. G. (1995). Metaphors for instruction: Why we talk about learning environments. Educational Technology, 35(5), 25-30. Retrieved from http://carbon.ucdenver.edu/ bwilson/wils95

Written communication. (2012). In Management Study Guide. Retrieved from http://www.managementstudy guide.com/written-communication.htm

Yancey, K. B. (2001). Digitized student portfolios. In B. L. Cambridge, S. Kahn, D. P. Tompkins, \& K. B. Yancey (Eds.), Electronic portfolios: Emerging practices in student, faculty, and institutional learning (pp. 15-30). Washington, DC: American Association for Higher Education.

Yasin, A.Y. M., Shaupil, W. M. H. W. M., Mukhtar, A. M., Ghani, N. I. A., \& Rashid, F. (2010). The English proficiency of civil engineering students at a Malaysian polytechnic. Asian Social Science, 6(6), 161-170. http://dx.doi.org/10.5539/ass.v6n6p161

Zubizarreta, J. (2004). The learning portfolio. Bolton, MA: Anker Publishing.

\section{Copyrights}

Copyright for this article is retained by the author(s), with first publication rights granted to the journal.

This is an open-access article distributed under the terms and conditions of the Creative Commons Attribution license (http://creativecommons.org/licenses/by/3.0/). 